\title{
Evolution of global oil benchmarks: new trends in pricing in the international oil market
}

\author{
Pavel Katyukha ${ }^{1}$ and Angela Mottaeva ${ }^{2,3,{ }^{*}}$ \\ ${ }^{1}$ Financial University under the Government of the Russian Federation, 49 Leningradsky Prospekt, \\ 125993, Moscow, Russia \\ ${ }^{2}$ Moscow State University of Civil Engineering, 26 Yaroslavskoye Shosse, 109377, Moscow, Russia \\ ${ }^{3}$ Moscow Region State University, Radio str., 10A, 105005, Moscow, Russia
}

\begin{abstract}
This article was prepared as part of the government contract as requested by the Ministry of Science and Higher Education of the Russian Federation on the subject formulated as «Structural changes in economy and society as a result of achieving the target indicators of National projects, which provide opportunities to organize new areas of social and economic activity, including commercial, both in Russia and abroad» (project No. FSSW-2020-0010).
\end{abstract}

\section{Introduction}

The shale revolution in the United States of America in the 2010s initiated profound changes in the structure of oil pricing in the world that has developed in recent decades [1]. Since 2011, there has been a gradual decrease in Brent oil production and now the Brent oil basket includes Brent, Forties, Oseberg, Ecofisk and Troll. The Brent benchmark, to which more than $70 \%$ of all oil traded in the world is tied, stagnates, loses its connection with the physical oil market and risks losing its status as a marker oil grade (benchmark). BFOE Blend Oil is the base grade for the European and Mediterranean markets and the BFOE Reference Price is used as a basis for determining the price level of other crude grades, taking into account their quality differences and delivery bases.

The United States is actively increasing oil production (by 2 times) and according to the BP Energy Statistical review, the production of liquid hydrocarbons, including gas condensate liquids (NGL), has reached a level of over 17 million barrels per day. Excluding NGL, oil and condensate production amounted to 12.23 million barrels per day. Of this volume, 7.7 million barrels per day. or $63 \%$ is accounted for by shale oil. The explosive growth of shale hydrocarbon production in the United States using the latest hydraulic fracturing technologies has turned American shale oil into a leading indicator of the oil market and a price marker (benchmark). This caused structural changes in the global energy market and created the conditions for a regrouping of the world's main oil benchmarks.

As a result of the transformation of the world oil market, since the mid-1980s. and to date, all world oil trade is conducted mainly with reference to three main international oil standards - benchmarks: European Brent, West Texas average WTI and Middle East Dubai

\footnotetext{
* Corresponding author: doptaganka@yandex.ru
} 
/ Oman, which, respectively, are traded on three exchange platforms - ICE ( Inter continental exchange), NYMEX (New York Mercantile exchange) and DME (Dubai Mercantile Exchange).

Brent and WTI crude oil futures are the most liquid contracts. Physicochemical and logistic differences between Brent and WTI lead to a difference in price and form the socalled spread between Brent and WTI, shown in Figure 1 [2]. Changes in this spread are influenced by factors such as the balance of supply and demand for crude oil in the United States, the level of oil production in the North Sea and geopolitical tensions that could disrupt the supply of crude oil in the world.

\section{Materials and Methods}

Oil, as one of the most important energy commodities, has turned into a financial commodity and has become an object of trade and global redistribution of income among the largest financial players. The volume of trading in financial derivatives (derivatives) significantly exceeded the volume of real hydrocarbons in the world. In fact, no more than $5 \%$ of futures contracts entered into on exchanges reach physical delivery.

As a result, financial institutions such as various hedge funds, pension funds and investment banks, which have become one of the most important instruments of the world economy and predetermined the transformation of commodity markets into a complex one, became the main players in shaping the price of all world oil. mechanism for conducting financial transactions.

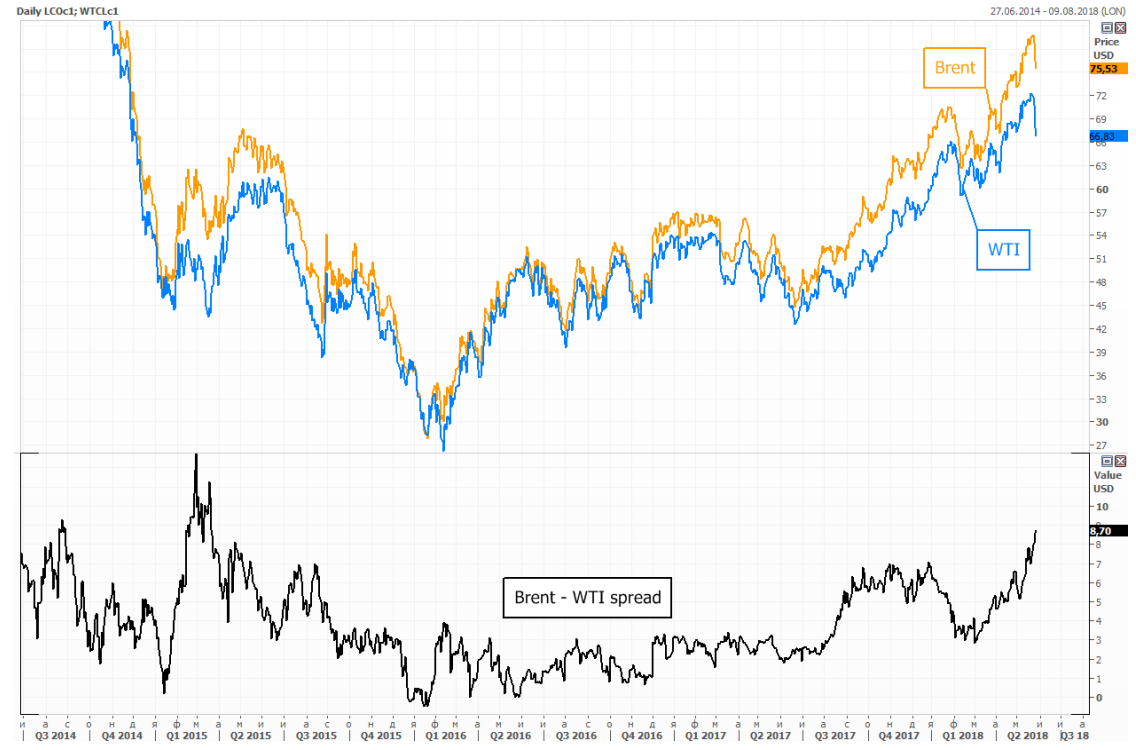

Fig. 1. The chart below shows the price difference between WTI and Brent.

Currently, Dated Brent is the most widely used in the world as an essential element of the price formula in contracts for the sale of physical oil of various grades. Platts, an international pricing agency, publishes daily estimates (quotes) of North Sea oil on the spot market for tanker shipments. More than $70 \%$ of all oil traded in the world is traded through a differential to the Brent benchmark. Its calculation is based on the market of forward contracts for oil of the oil basket of the same name.

The methodology for assessing the named benchmark is complex and multi-stage and not always transparent, which is caused by the difficulty of identifying the current price of 
tanker shipments of crude oil. The North American WTI price benchmark is the settlement price for a futures contract on the New York Mercantile Exchange for the oil of the same name. This is due to the fact that pipeline delivery is a few days away from the expiration date of the "WTI futures" and implies uniform pumping of a batch of raw materials during a calendar month, while the shipment of a tanker (for example, such grades as Brent, Dubai, Urals) is delayed from the date of the contract is for several weeks and takes 3-5 days.

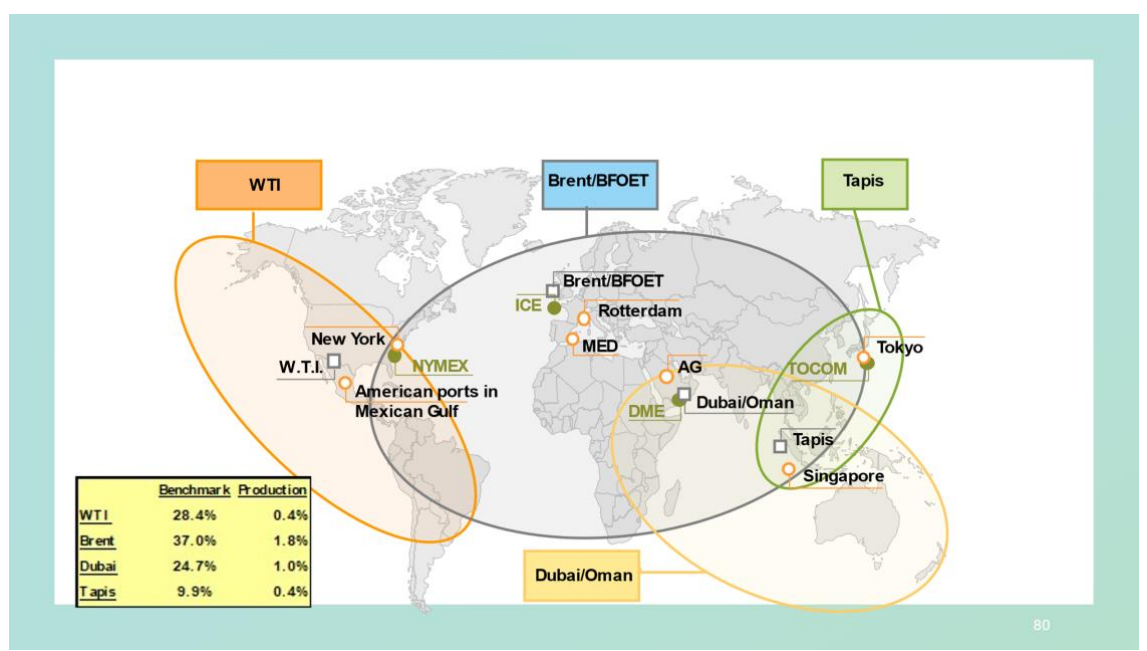

Fig. 2. Oil spot and futures trading centers in the world. Note: Compiled by the authors based on API.

A marker grade of oil (benchmark) is a grade of oil with certain physicochemical properties used to determine the quoted price of oil in a particular regional market. The main feature of the benchmark, which distinguishes it from all other grades of oil in the world, is the presence of a quotation, which is expressed in absolute value and differential (discount / premium). Prices for other grades are determined through differentials for marker grades of oil. To form a price standard based on a particular grade of oil, the latter must meet a number of requirements, without which the transition to the category of marker grades is impossible. The most important of them are:

- significant volumes of production and sales of this grade of oil on the world market, sufficient to protect its participants from price manipulations;

- stable quality of oil supplied to the market;

- well-developed transport and logical infrastructure with adequate capacities for the transportation, storage and shipment of oil, and does not create problems in its sale, that is, provides access to this grade for a large number of international buyers;

- standardized General Terms and Conditions (GTCs) of the physical oil purchase and sale contract used by all market participants, which, in particular, is a condition for the emergence of a secondary market for this grade.

However, the scale of exchange transactions with oil contracts for these grades of oil is not only many times higher than the level of their production, but is comparable in some cases with the volume of world oil production. West Texas oil was originally the benchmark grade in international trade, as the US was the main exporter, most of the American companies were in the market, and the pricing formula was tied to FOB Gulf of Mexico prices. The difference in price for a given grade of oil in relation to the "reference" is called the price differential:

Price $($ oil grade $)=$ Brent $(\mathrm{dtd})$ North sea dated $($ standard $)+/$ - differential. 
The differential is the sum of all costs incurred in transportation, delivery, insurance, change in oil quality per barrel or ton. The market differential is not constant and is updated on an ongoing basis.

By this moment, the structure of the world oil market has undergone significant changes, which has led to the transformation of the "physical" spot market, where cash oil is traded, into a "paper" derivatives market, where only futures contracts for oil are traded (the main world benchmarks are WTI, Brent / BFOE and Dubai / Oman), shown in Figure 2. As a result, the world system of exchange trading in oil and oil products was formed, served mainly by three exchanges.

Considering the multi-layered macroeconomic and microeconomic factors affecting the price of oil in the world market, including the lifting of the ban on oil exports from the United States and the reopening of oil reserves in the United States in December 2015.And, accordingly, an increase in oil production, as shown in Figure 3 (https://www.eia.gov/dnav/pet/hist/LeafHandler.ashx? $\mathrm{n}=$ pet\&s=mcrfpus1\&f=al), an be assumed that the WTI benchmark on NYMEX intends to squeeze out Brent on ICE, which traditionally trades at a premium to WTI, which has more liquidity.

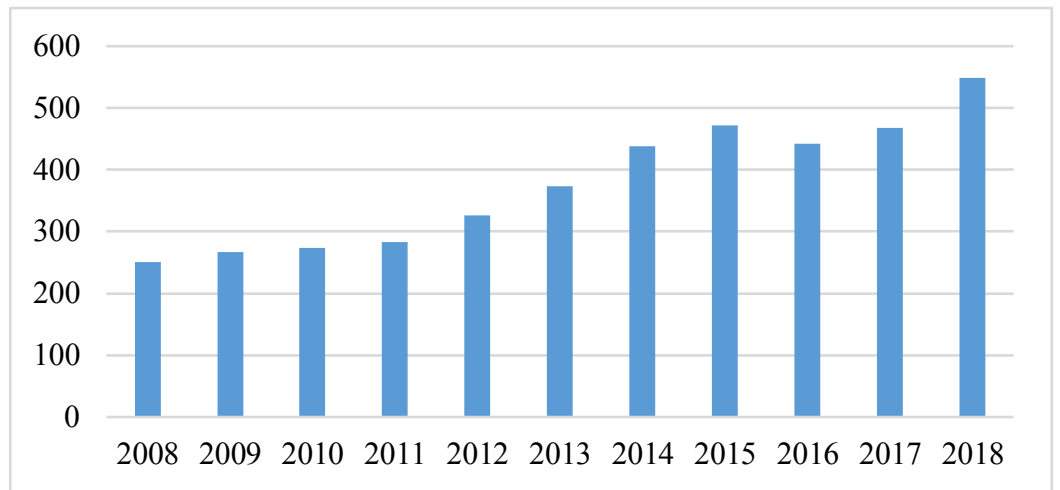

Fig. 3. Oil production in the United States in the period 2008-2018 (million tons).

Currently, commodity exchanges are a universal institution for regulating market relations - supply and demand in the oil market and perform functions specific to the economy, which include not only identifying an objective and transparent price, but also managing price risks by hedging).

Commodity exchanges are a universal tool for regulating market relations - supply and demand in the oil market - and perform functions specific to the economy:

- identification of an objective and transparent price;

- price risk management, including the transfer of price risk through hedging;

- diversification of transactions (in terms of the transition from paper to physics);

- investments (in terms of asset optimization and purchase of futures for investment and speculative purposes);

- arbitration (as an opportunity to make a profit using spreads and an arbitration window);

- creation of general price indices for the conclusion of long-term, formulaic contracts and equal access to price information.

Despite the fact that prices for the main reference oil grades (benchmarks) are formed on exchanges, the so-called "estimates" of the state of the physical oil market - the basic asset for exchange quotations - are determined by international price agencies (Platts and Argus). The valuation methodology of these price agencies is not sufficiently objective, because it is based on information about physical oil transactions and does not reflect the huge number of futures transactions in the derivatives market. 
This information reflects the intentions of the parties, rather than the actual physical oil transactions concluded, in which such important components of the physical oil trade as freight rates, demurrage, the quality of the goods shipped, the cost of hedging, etc., remain undisclosed.

When calculating prices on the domestic market, an important indicator for Russian and foreign oil and gas companies is the comparability of income from exports and domestic supplies, which is also called the export equivalent, which is calculated using the net-back method. The published values of the export equivalent do not represent the actual export prices, but characterize the average current and expected efficiency of oil exports. The calculation of the export equivalent from the spot quotations of Urals oil is carried out according to the formula:

Export equivalent $=$ Oil price on the terms "FOB port of loading on a tanker" Transhipment costs - Customs clearance - - Export duty (*) - Transportation costs from the manufacturer's CU to the loading port + VAT $18 \%(*)$ duty of the current calendar month is used from 1 st to 14 th day of the month inclusive; from the 15 th to the last day of the month, the duty of the following month is used.

\section{Results}

A significant reduction in the production of North Sea Brent oil leads to a decrease in its global importance as a reference grade of oil and the world oil market needs a new marker grade of oil (benchmark) for medium-sulfur crude. The confrontation between the two main benchmarks of WTI and Brent, which has escalated in recent years, indicates that the interest of financial speculators (investors) on the NYMEX is gradually shifting from trading in Brent futures to trading in WTI futures, which causes similar changes. and on the spot and forward oil markets. In the past, WTI traded at a premium to Brent. However due to the Shale Revolution in the early 2000s (in which WTI production increased) and more imports to the US from Canada, the price of WTI declined. It now usually trades at a discount to Brent. Today WTI is the benchmark for oil prices in the US, while the rest of the world - and nearly two-thirds of all oil contracts traded - are on Brent. This makes Brent the global Benchmark. The price difference between WTI and Brent is known as the WTI vs Brent Spread. The spread will change from time to time, as the supply and demand forces of each crude oil are elastic due to geopolitics, weather, and regulation.

The shale revolution in the United States of America has become a powerful driver for the entire world oil market and led, first of all, to an increase in the production of hard-torecover oil in the United States (from 2008 to 2018, more than 2 times: from 1.83 billion barrels / 250 million tons to 4, 0 billion barrels / 550 million tons, respectively) and the emergence of new sales markets, new bases and centers for fixing prices, which had a great impact on the balance of forces in the structure of world oil pricing. The WTI price benchmark got a good chance to oust the North Sea Brent benchmark from the pedestal of the world marker grade of oil, taking into account the fall in volumes and the loss of liquidity, and to form its new, reconstructed WTI price benchmark. The assumed baseline could consist of three potential benchmarks: WTI Cushing - WTI Midland - WTI Houston.

The spot (physical) and futures (paper) markets are closely interconnected through the basis and the formation of a new basis depends, first of all, on the development of the market for physical oil exported from the United States, the construction of new terminals and on changes in the transport and logistics infrastructure of the United States, as shown in Figure 4 [4]. It should be noted that, until recently, the United States was the world's largest producer and consumer of oil in the world. Between the global oil market and the physical shale production of the Permian, Eagle Ford and other basins, a long transport and logistics 
chain of pipelines, oil storage facilities, ports and oil tankers was built with a number of constraining factors, which required the creation and launch of new futures contracts:

- NYMEX WTI / Cushing WTI / WTI Cushing - WTI qualifying for a futures contract launched in March 1983 by the New York Mercantile Exchange (NYMEX) for delivery in Cushing, delivered there via Enterprise Products Partners or Enbridge Pipeline;

- Permian WTI - WTI, directly delivered from West Texas to the Magellan Midstream Partners terminal in Houston through the pipelines of this company; is the underlying asset of the Intercontinental Exchange (ICE) futures (code: HOU), launched in October 2018;

- WTI Houston - WTI delivered directly from West Texas to the terminals of Enterprise Products Partners in Houston via this company's pipeline; is, in particular, the underlying asset of a futures (code: HCL) of the New York Mercantile Exchange (NYMEX), launched in November 2018;

- Midland-grade WTI - WTI delivered to the point of sale directly from West Texas and free from additives after being brought to the surface;

- WTI Midland - WTI at the price fixing point in the town of Midland in the south of Texas, in the immediate vicinity of the place of its rise to the surface;

- WTI MEH - WTI delivered directly from West Texas to the Magellan Midstream Partners terminal in Houston; the designation, in particular, is used by the price agency Platts;

- WTI FOB USGC - WTI directly delivered from West Texas to any of the terminals on the Gulf Coast; the designation is used by the Platts pricing agency;

- WTI Cactus - WTI delivered directly through the Cactus pipelines from west Texas to terminals in Corpus Christi in southern Texas.

Comparison of the price of one or another North American oil with the price of a WTI futures contract (with delivery in Cushing) is no coincidence [6]. West Texas light, lowsulfur WTI (West Texas Intermediate) crude oil occupies a special place not only in the North American, but also in the world market. This is the most powerful oil flow in the United States, thanks to which it was put in the basis of a futures contract launched in 1983 on the New York Mercantile Exchange ("WTI futures"), the price of which has become one of the price benchmarks since the late 1980s (so called "benchmarks") of the world oil market, that is, a price indicator in relation to which other varieties, both North America and imported by the United States, are traditionally evaluated.

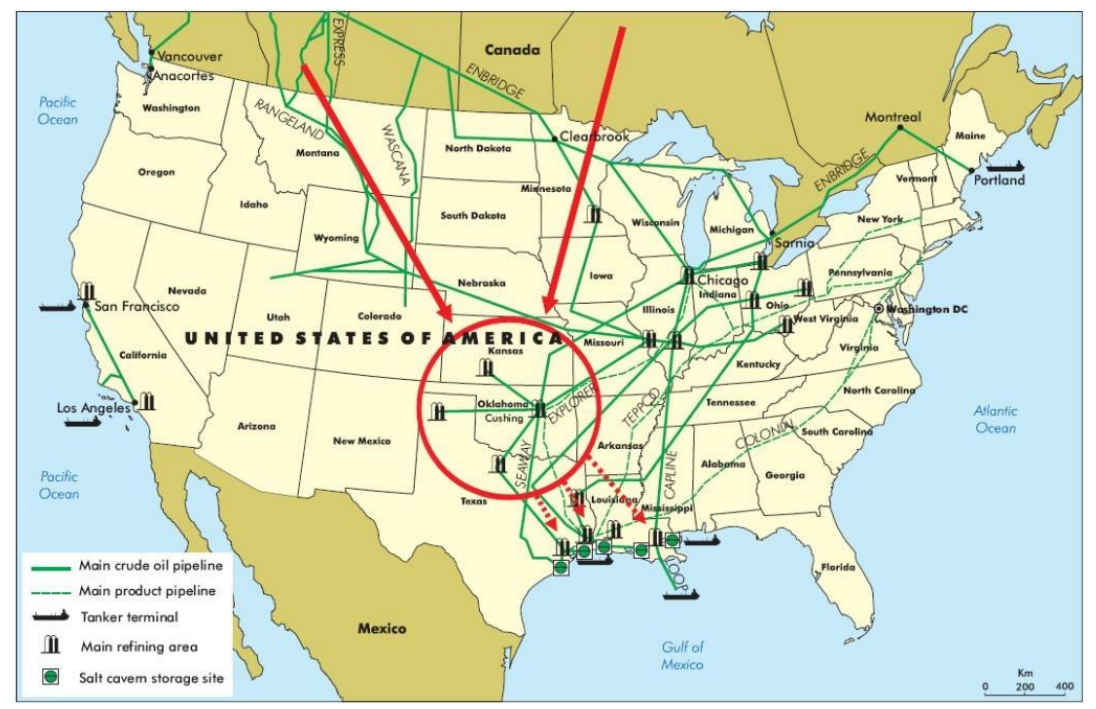

Fig. 4. Cushing-WTI fixing point. Note: Compiled by the authors based on API data. 
An important factor testifying to the change in the structure of the world commodity market is the formation of a new exchange ICE Futures Abu Dhabi (IFAD) created by the Abu Dhabi National Oil Company (ADNOC) in the United Arab Emirates with a center in Abu Dhabi with a benchmark based on the Murban oil grade [3] ... The world's leading majors BP, Total and Shell, as well as traders Vitol and South Korean GS Caltex, Japanese INPEX and JXTG, Petro China, Thai PTT have confirmed their agreement to become partners. This means that the new exchange will trade the first deliverable futures contracts for Murban oil, which is produced by ADNOC.

The partnership of such major global players in the oil market demonstrates the serious intentions of ADNOC and is an important signal for market participants about the claims of the Murban marker to become a new global benchmark. Launching on a new exchange in Abu Dhabi, Murban's deliverable oil futures will be secured by the physical delivery of oil at the Fujairah port in the UAE. Murban is a sweet crude produced by the national company ADNOC. The company produces about 3 million barrels of oil per day, of which Murban accounts for about 1.7 million $\mathrm{b} / \mathrm{d}$ [5]. The launch of a new pricing mechanism for Murban oil involves the creation of a new price benchmark (reference grade of oil), which will be determined by the market, or rather by market participants and may become a new representative marker grade of oil for oil produced in the Middle East and sold in the AsiaPacific zone.

The growing confrontation between the two leading world benchmarks - WTI and Brent - gives Russia a unique chance not only to create a Russian benchmark for Urals oil and conditions for transparent and independent pricing, but to form a full-fledged derivatives market using a variety of exchange instruments. At present, prices for Russian oil exported are determined by international price agencies with reference to the North Sea Brent reference grade (benchmark) using a differential formula (discount or premium). By the early 2000s. in Russia, all the necessary conditions have ripened for the emergence of a large competitive exchange commodity platform, which will create a transparent exchange mechanism for the formation of wholesale prices for petroleum products.

World practice shows that the exchange, as an infrastructure organization that forms the spot and derivatives markets, allows using modern exchange technologies to successfully solve the problem of increasing the transparency of pricing for oil and oil products by creating mechanisms that stimulate competition among participants in the domestic oil and oil products market. With the aim of forming an organized commodity market in Russia, creating objective market indicators for the most significant commodities, by the decision of the Government of the Russian Federation in May 2008, the St. Petersburg International Commodity and Raw Materials Exchange CJSC was registered. The main task of the exchange was the formation of an organized commodity market and the creation of an independent and transparent pricing system.

To create a full-fledged exchange infrastructure that meets international exchange trading standards, the Russian exchange must have a full range of appropriate tools and mechanisms. According to stock analysts, the creation of exchange infrastructure similar to those with which the world's largest exchanges, such as NYMEX or ICE, can take more than one or two years. The Russian Federation is one of the largest suppliers of hydrocarbons for export. The flow of Urals oil through the ports of Primorsk, Ust Luga, Novorossiysk exceeds 2 million barrels. per day, through the Druzhba pipeline - more than 1 million barrels. per day. ESPO oil is exported in volumes of about 1 million barrels. per day. It should be noted that the export of Russian oil of Urals and ESPO grades to international markets is twice the supply of oil from the North Sea basket of BFOE, Oman and Dubai combined. Europe is the largest consumer of Russian oil and is historically quite heavily dependent on Russian exports, which account for almost $40 \%$ of all European net 
imports. In addition, Russia supplies to Europe $85 \%$ of the total volume of imported diesel fuel in this region.

As for the export of Russian oil for the Asia-Pacific region market, according to experts, by the end of the decade, oil consumption from China is expected to grow by an average of $2 \%$ per year [2]. In addition to China, the growth of the economies of India, Vietnam, the countries of South America and the Middle East shows a trend towards an increase in demand in the APR. The stable quality and uniformity of the Russian export mixture, the regularity of supplies and the vast geography of exports create favorable conditions for the formation of our own marker oil grades on the basis of stable export flows of Russian oil. To start trading in futures contracts for Urals oil with the possibility of settlement, it is necessary to develop a market-acceptable methodology for calculating the Urals oil price index. An important characteristic of this technique is its reliance on the prices of export transactions with Russian export oil. The main goal of launching the Urals benchmark project is to create a new pricing mechanism for Urals crude oil through direct market pricing, without reference to other oil benchmarks and actually bridging the gap between prices in the physical and paper oil markets.

For this purpose, on November 29, 2016, a futures contract for the Russian export oil Urals was launched on the SPIMEX exchange floor on FOB delivery terms to the port of Primorsk. The volume of the contract is 1,000 barrels, the delivery batch is 720 thousand barrels. (100 thousand tons), contract currency - US dollar. Rubles, along with other assets, are accepted as security for the conclusion of exchange transactions. It should be especially noted that the strategic project of SPIMEX to launch a Russian benchmark for export mixture will allow Russian companies to act not as "price takers" but as "price makers" on the world crude oil market. This is very important in the context of sanctions and a complex geopolitical situation.

The creation of a pricing system based on our own reference grade of oil can bring additional revenues from each barrel of exported raw materials, which is in the interests of both exporting companies and the Russian budget. To bring a new benchmark to the international oil market, a number of important conditions must be met: the oil price must be formed transparently and competitively, pricing must be decoupled from other varieties of the foreign market, the market must be legally regulated and have clear rules, and contracts must be standardized.

\section{Conclusions}

As a result of the analysis of the evolution of the pricing structure of the world commodity market, it can be concluded that competition between the main world benchmarks for oil, such as Brent, WTI and Oman / Dubai, is gaining momentum. The comparative analysis method used by the authors demonstrates the interconnection of various factors and phenomena of the world oil commodity market, such as physical and paper oil, spot, derivatives and financial markets, futures and forward contracts. The article shows the strengths and weaknesses of various benchmarks that affect different sectors of the economy.

The use of the comparative analysis method allows us to understand the depth of the geopolitical, economic and financial events taking place in the global energy market, which have a significant impact on the pricing of the main grades of oil. In particular, the events taking place in the Middle East, the position of the OPEC + countries, have an impact on the Brent benchmark, to which the oil produced in the Middle East is tied, which makes up more than half of all world reserves. The formation of the new ICE Futures Abu Dhabi (IFAD) exchange set up by the Abu Dhabi National Oil Company (ADNOC) in the United Arab Emirates demonstrates the UAE's desire to strengthen its position in the Middle East 
price benchmark. The launch of a Russian futures contract for Russian export Urals oil on FOB terms at the port of Primorsk indicates Russia's desire to move away from being tied to the Brent price benchmark.

\section{References}

1. N.A Ivanov, Slantsevaya Amerika: energeticheskaya politika SShA i osvoyeniye netraditsionnykh neftegazovykh resursov (M., Magistr, 2014)

2. P.B. Katyukha, Trade in hydrocarbons on world energy markets (M., Rossiyskiy gos. un-t nefti i gaza imeni I.M. Gubkina, 2015)

3. Crude oil: The Murban makeover, https://www.argusmedia.com/ru/blog/2019/august/9/ crude-oil-the-murban-makeover

4. U.S. Field Production of Crude Oil / US Energy information agency, https://www.eia.gov/dnav/pet/hist/ LeafHandler.ashx?n=pet\&s=mcrfpus $1 \& \mathrm{f}=\mathrm{a}$

5. Eaton C. CORRECTED-U.S. Midland crude discount narrows to seven-month low // Thomson Reuters, https:/www.reuters.com/article/usa-crude-midland/corrected-u-smidlandcrude-discount-narrows-to-seven-month-low-idUSL2N1WZ0RX

6. Texas Field Production of Crude Oil / US Energy information agency, https://www.eia.gov/dnav/pet/hist/ LeafHandler.ashx?n=pet\&s=mcrfptx $1 \& \mathrm{f}=\mathrm{a}$

7. N.Y. Ryazanova, A.V. Sharkova, N.E. Lobzhanidze et al., International Journal of Recent Technology and Engineering 8(1), 2691-2695 (2019)

8. Y.V. Morozyuk, A.V. Sharkova, I.A. Merkulina et al., Journal of Environmental Management and Tourism 8.3(19), 507-515 (2017) DOI: 10.14505/jemt.v8. 3 (19).02

9. A. Nassyrova, Z. Yessymkhanova B. Issayeva et al., Entrepreneurship and Sustainability Issues 8(1), 640-655 (2020) DOI: 10.9770/jesi.2020.8.1(44)

10. G. Nurzhanova, G. Mussirov, S. Niyazbekova et al., Entrepreneurship and Sustainability Issues 8(1), 656-671 (2020) DOI: 10.9770/jesi.2020.8.1(45)

11. E. Karieva, L. Akhmetshina, A. Mottaeva, E3S Web of Conferences 217, 07008 (2020) https://doi.org/10.1051/e3sconf/202021707008

12. N.S. Shcherbakova, Y.A. Nazarova, N.A. Navrotskaia et al., International Journal of Energy Economics and Policy 10(5), 401-408 (2020) DOI: 10.32479/ijeep. 9627

13. N.O. Kurdyukova, M.A. Menshikova, M.D. Dzhamaldinova, EEE International Conference "Quality Management, Transport and Information Security, Information Technologies", IT and QM and IS, 246-248 (2020) DOI: 10.1109/ITQMIS51053.2020.9322970

14. I.Y. Novoselova, I.V. Petrov, A.L. Novoselov, Ugol 8, 88-91 (2020) DOI: 10.18796/0041-5790-2020-8-88-91

15. E.M. Deyanov, N.A. Kharitonova, IOP Conference Series: Materials Science and Engineering 976 (2020) DOI: 10.1088/1757-899X/976/1/012034 